\title{
The Discomfort of Intercultural Learning in Music Teacher Education
}

\author{
Alexis A. Kallio and Heidi Westerlund
}

\begin{abstract}
Recognizing and ethically engaging with the inherent diversity of music education contexts demands a continuous interrogation of the norms and values underpinning policy and practice in music teacher education. In doing so, teachers and students in higher education are challenged to question why and how students are socialized into particular music education systems, traditions, or perspectives and to consider alternatives. In this chapter, we explore such reflexive processes, employing a theoretical reading analysis through Bourdieu's concepts of habitus, and doxa. The data consists of group reflections and interviews with student-teachers that the authors conducted as part of an intercultural arts education project between Finnish masters students and two Cambodian NGOs. Based on our analysis, we argue that stepping outside of one's cultural, musical, and pedagogical comfort zone is a necessary component of constructing and (re)negotiating teacher visions in music teacher education. However, this renegotiation may be discomforting for student-teachers, unsettling deep-seated visions of what good music education is and ought to be - the taken-for-granted doxa of music teaching and learning. Therefore, for music-teacher education to become transformative and reflexive, there is a need for such educational experiences that engage with processes that are related to the art of living with difference.
\end{abstract}

Keywords Bourdieu · Discomfort - Intercultural education · Music teacher education $\cdot$ Reflexivity

A. A. Kallio $(\bowtie) \cdot H$. Westerlund

Sibelius Academy, University of the Arts Helsinki, Helsinki, Finland

e-mail: alexis.kallio@uniarts.fi; heidi.westerlund@uniarts.fi 


\section{Introduction}

As school and university populations are increasingly recognized as inherently diverse, visions for higher music education have shifted from the transmission of skills or knowledge to social and ethical commitments to engage with difference. Whereas once, education institutions may have been seen to "provide a haven against social and cultural change" (Gates 2009, xxii), increasing mobility, migration and technological advances now position them at the forefront of learning what Zygmunt Bauman has called "the art of living with difference" (Bauman 2010, 151). In Finland, national government policy (Opettajankoulutus 2020) has highlighted the need to foster intercultural competencies among future teachers in order to respond to a fast-changing socio-cultural climate and to strengthen democratic practices in schools. Such imperatives require a shift in focus in higher music education from deepening skills and understandings of what is already known, to a "complete reconceptualization of (...) practices and of [the] obligation to partake in global discourses and discussions" (Karlsen et al. 2016, 371). This poses significant challenges to the values and practices that have long been taken for granted - what the sociologist Pierre Bourdieu refers to as doxa. With etymological roots in the Greek verb $\delta о к \varepsilon \tilde{\nu}$ - to appear, or to accept - doxa functions to naturalize and normalize social practices. As many of our activities in music education are based on historical traditions and are guided by habits and emotions, the musical, pedagogical and onto-epistemological differences encountered through globalization may well appear threatening (Bauman and May 2001), as they disrupt tacit logics and understandings. These disruptions may be felt particularly violently in the context of music teacher education, often within conservatoire settings and structured according to firmly established musical, cultural, and pedagogical values. However, if the social and ethical imperatives of intercultural engagements are to be taken seriously, music teacher education can no longer assume that students can, want to, or should be socialized into a single music education system, tradition, or perspective (Kertz-Welzel 2013). Rather, contemporary societal changes demand an interrogation of why it is that we "teach students particular things and socialize them in particular ways" (Schubert 2008, 188).

As the norms and values of higher music education are called into question, the underlying doxa may be identified and reflected upon, creating alternatives to the commonsensical scripts of what, why and how we teach and learn. These scripts of music-teacher education can be understood in terms of what Bourdieu referred to as the logic of the field (Bourdieu and Passeron 1990). Those who possess cultural capital (in the case of many music-teacher education programs, a strong background in western art music and learning within vocation-based, master-apprentice models) are often comfortable within the field of higher music education. They are able to position themselves strategically, being familiar with the doxa and scripts of how and why things are done. In culturally diverse music education contexts (i.e. all music education contexts), if this logic is available to some and not others, those whose cultural capital does not align with the doxa of the field are excluded. As 
such, comfort is not an indicator of 'smooth sailing', but of privilege, inequality, and insularity - qualities that music teacher education programs can ill afford in an increasingly globalized world. From this perspective, consensus is impossible and indeed undesirable (Mouffe 2005). Furthermore, the discomforting sense of being outside of one's comfort zone is not a situation to be avoided in music-teacher education, but an essential component of ethical intercultural teaching and learning (see e.g. Westerlund 2017; Westerlund et al. 2015; Saether 2013; Bradley 2007).

In this chapter, we reflect upon the potentials of discomfort in the construction and (re)negotiation of teacher visions in higher music education. According to Karen Hammerness (2015), visions of what constitutes good teaching establish a sense of purpose with regards to what should be taught, who should be taught, and importantly, how we teach and why. Guiding decision-making and actions, visions are not necessarily utopian goals but represent teachers' strivings, imaginations, commitments, and understandings of classroom actions (Hammerness 2015, 8). However, Hammerness notes that "a program that is too closely focused and organized around a particular vision may deter candidates from expressing or developing alternative perspectives or exploring their own personal visions (...) potentially masking any challenges, differences, or variations" $(2015,6)$. Furthermore, as Talbot and Mantie explain, this is particularly problematic if visions "operate to advantage certain musical practices over others and, in so doing, advantage some groups of people over others" $(2015,156)$. If visions are to "promote both a vision of teaching as a professional practice as well as teaching as a means of making a difference" (Hammerness 2015, 18), we here consider how visions might challenge the doxa of music teacher education in ethically teaching and learning 'the art of living with difference'; how alternative perspectives are included and welcomed; and what possibilities exist in practice to learn outside of, or in opposition to the institutionalized, unreflective shared understanding of what good music teaching is.

\section{Research Context: Multicultural Arts University}

This chapter draws upon findings from research conducted during the second-cycle of an intercultural project titled Multicultural Arts University (see Westerlund et al. 2015 for more on the first-cycle of this project). This cycle of the project involved seven masters-level music education students, one music technology student and one dance student from the University of the Arts Helsinki, travelling to three music and dance programs run by two Cambodian Non-Governmental Organizations (henceforth NGOs) in 2013. ${ }^{1}$ The masters student-teachers from the University of the Arts Helsinki were accompanied by four university staff members, including the authors of this chapter, and two music education lecturers. Although facilitated by the university and granting study credits, the project was not a mandatory part of

\footnotetext{
${ }^{1}$ This project was funded by the Ministry for Foreign Affairs of Finland. More information can be found at http://mcau.fi
} 
their studies but an exceptional situation and opportunity. Participating studentteachers were selected from applicants on the basis of certain criteria, including being in the final stages of their university studies, and having previous travel experiences.

The first NGO that participated in this project, which we here refer to by the pseudonym New Horizons Children's Community (henceforth New Horizons), was located on two sites: in Siem Reap in the North of Cambodia, and in the capital city Phnom Penh. New Horizons was primarily a residential home (for approximately 60 children at the Siem Reap community, and over 100 children at the Phnom Penh community), and offered regular lessons in music and dance for the children living there (in traditional Cambodian musics and dance, but also western art and popular music and dance styles). The Finnish student-teachers spent 2 days at New Horizons Siem Reap, and 4 days at New Horizons Phnom Penh. Student teachers conducted small and large group workshops for children, and also engaged in individual instrumental tuition when requested. This work culminated in a one-hour collaborative performance for the New Horizons community, including children and staff. A longer period of time, 10 days, was spent at the second NGO, which we refer to through the pseudonym Komar Chrieng. Located in a small town in the rural Southern coastal region, Komar Chrieng was home to a much smaller group of children (approximately 20), but had opened its doors to hundreds of local children to learn traditional Cambodian musics and dances free of charge. The Finnish studentteachers conducted small and large workshops on Finnish folk music and popular music, and in turn, the Cambodian children and staff members taught the student teachers a number of traditional Cambodian musics and dances. ${ }^{2}$ At Komar Chrieng the teaching and learning between student-teachers and Cambodian children culminated in a public fundraising-performance for the local community and tourists.

This intercultural teaching and learning project aimed to provide both the Finnish student-teachers and the Cambodian children with opportunities to teach and learn from one another, in many ways following ethnomusicological approaches that are centered on getting to know cultural and musical Others (see e.g., Belz 2006; Campbell 2004; Joseph and Southcott 2009; Schippers 2010; Volk 1998). For the Cambodian children, the project also aimed to create a space of empowerment. This was not only through providing an opportunity for them to teach adult foreigners,

\footnotetext{
${ }^{2}$ These traditions included Pinpeat music, Mahori music, folk music and dance, classical dance and Yike theatre. Pinpeat music dates back to the ninth century and is primarily ceremonial or religious music played on wind and percussion instruments; Mahori is composed of two music forms, one traditionally designated for the Royal courts, and the other which is primarily performed at wedding celebrations. Folk music and dance often depict scenes of everyday rural Cambodian life and livelihoods. Classical dancers were traditionally sourced from all parts of Cambodian society, from the peasantry to the aristocracy, and were trained from childhood at the Royal Palace. Dancers were seen as the earthly counterparts to the entertainers of the Gods, the Apsara and Devatas, and were revered accordingly. Yike theatre incorporates a singing style reminiscent of Cham and Malay Islamic traditions. Consisting of both singing and dancing, Yike performance depicts local legends, mythology and humour in community settings (see Cravath 2007) and is now a highly endangered tradition in Cambodia.
} 
but also to have a sense of ownership and pride in Cambodia's cultural traditions, some of which are highly endangered due to the genocidal regime of the Khmer Rouge in the 1970 s and consequent political conflicts. For the Finnish studentteachers, the project aimed to offer an intercultural "immersive learning experience" (Bartleet 2011, 12). Access to these sites was agreed beforehand by communication between NGO leaders and project leaders (including the two authors of this chapter) which took place via email as well as during a preparatory visit conducted prior to the intercultural exchange. This preparatory visit entailed co-planning the project, aiming for teaching and learning to be context-sensitive and beneficial to all involved. Student-teachers and project leaders all adhered strictly to the ethical guidelines and rules provided by each NGO institution with regards to interacting with children. Data was not collected from children and all interviews with studentteachers were held outside the NGO premises.

\section{Methodological Approach}

All student-teachers gave their informed consent to participate in this study, and were informed that they could withdraw at any time. The data for this study were collected through: audio recordings of interviews conducted with Finnish studentteachers, both individually and in small groups, by the second author of this chapter and one of the lecturers; a shared pedagogical reflection where both authors of this chapter were present; and eight student-teacher group reflections led by one of the lecturers (see Table 1).

In the interviews, the Finnish student-teachers were asked about the role(s) they assumed during teaching and learning, comparisons between the teaching and learning contexts of Finland and the Cambodian NGOs, their thoughts about working together with the Cambodian staff and children, and how they envisioned that they might apply what they had learnt in the future. The group reflections focused more on their daily activities, teaching, and self-defined learning. The pedagogical reflection centered on a reading of an academic text (relating to intercultural teaching and learning) and the student-teachers' reflections in relation to the intercultural project.

Table 1 Data sources

\begin{tabular}{l}
$2 \times 3$, approx. 45 -min-long, semi-structured group interviews ( 3 student-teachers in each \\
group) ${ }^{[3]}$ at New Horizons Siem Reap; New Horizons Phnom Penh; and Komar Chrieng \\
\hline 8 semi-structured, 20- to 50-min-long, individual interviews conducted halfway through the \\
exchange project \\
\hline $\begin{array}{l}45 \text {-min-long, shared pedagogical reflection session conducted halfway through the exchange } \\
\text { project }\end{array}$ \\
8 student-teacher group reflections ( $2-3$ in each reflection group) facilitated by the university \\
lecturer participating in the exchange project; these reflections ranged between 10- and \\
45 -minutes in duration
\end{tabular}


The interview audio recordings were professionally transcribed and translated into English (the native language of the first author of this chapter).

We (both authors of this chapter) approached the data through what Jackson and Mazzei (2012) term "thinking with theory". As a qualitative "post-framework" (2012, ix), the data was read with Bourdieu, approaching the stories and experiences that student-teachers shared not as some " 'thing' that has happened 'to' them, but [as] something that has been filtered, processed, and already interpreted" (Jackson and Mazzei 2012,3). Furthermore, whilst the student-teachers' experiences are the focus of this chapter, as teachers and researchers participating in the same project, we were also contending with our own discomforts, intercultural learnings, and challenges; as such, we could not approach the theory or data as objective outsiders. In acknowledging that student-teachers' shared reflections were already selective and selected, we also note here that "putting philosophical concepts to work" is not merely interpretative. As Bourdieu cautions, researchers should be put "on notice against the fetishism of concepts, and of 'theory,' born of the propensity to consider 'theoretical' instruments-habitus, field, capital, etc. - in themselves and for themselves, rather than to put them in motion and to make them work" (Bourdieu and Wacquant 1992, 228). In this sense, our thinking with theory is constitutive (Jackson and Mazzei 2012) - a means to "produce different knowledge and to produce knowledge differently" (St. Pierre 1997, 175). Through pulling the data out of shape through a theoretical frame, and pulling the theory out of shape through the data, the data is lived in new ways, and can be understood as an ethical intervention and invention itself (Lather 2016, 104). The findings presented in this chapter are crafted in the form of composite narrative accounts, a first-person voice that draws upon the stories of many participants (Kallio 2015; Bresler 2005). Illustrating the discomfort and learning that took place, the excerpts here weave together voices of agreement, but also highlight tensions that arose within the group, without sacrificing the anonymity of individual participants (Leavy 2013). In this sense, the excerpts included in this chapter do not represent any single person in particular, but assume a "fiction[al] form... laid over a 'fact-oriented' research process" (Agar 1990, 74).

\section{Disrupting the Visions of Good Music Teaching: Student- Teachers' Journeys from Discomfort to Reflexivity}

Bourdieu posits that agents mobilize different forms of capital (such as cultural, artistic, religious, pedagogical and so forth) in order to gain currency and position themselves within different fields. "[E]ach field prescribes its particular values and possesses its own regulative principles", delimiting "a socially structured space in which agents struggle, depending on the position they occupy in that space, either to change or to preserve its boundaries and form" (Bourdieu and Wacquant 1992, 17). This suggests that the field is one of continual comparison, conflict and contestation - the site of transformative possibility. In this sense, fields are "a space of play 
which exists as such only to the extent that players enter into it who believe in and actively pursue the prizes it offers" (Bourdieu and Wacquant 1992, 19). Furthermore, agents are able to negotiate or transform the field to various degrees, depending on the capital they may possess, according to the logic of that particular field. In this section of the chapter we present our analysis of the discomfort that student-teachers experienced during the intercultural project. These student-teachers may be seen to be actively pursuing the "prize" of intercultural competence in arts education, and possess considerable cultural and artistic capital within the field of higher arts education in Finland. However, the new fields of the Cambodian NGOs disturbed student teachers' habitus by disrupting the musico-pedagogical scripts of teaching and learning music, and instigating new learnings. Through the narrative excerpts shared in this section, it is possible to follow the student-teachers' journeys from the discomforting of shared and accepted visions of music education, to reflexive and transformative possibility.

\subsection{A Crisis of Certainty: Different Agents, Different Fields}

As part of the intercultural project, the Finnish participants assumed that all of the children involved in the intercultural immersion project had experienced various hardships, as informed through communications with the Cambodian NGO staff members. These included: the death of parents or other family members; the incarceration of parents or family members; being abandoned or placed in temporary care as the result of economic hardship, disability, or illness; being rescued from child trafficking networks; having been removed from family environments by government agencies in response to various forms of abuse; health conditions such as HIV; and so on. Whilst the Finnish student-teachers were not provided with information regarding particular children or groups, they were aware before they travelled to Cambodia, that the children they were working with represented significantly underprivileged and marginalized social groups and had life experiences very different from their own. However, how these personal histories were manifest in the present often differed greatly from their expectations. The Finnish student-teachers explained that they found it difficult to grapple with their own partial understandings, prejudices, and perspectives as to who the Cambodian children were.

\footnotetext{
I was more prepared for very poor conditions, expecting that the children would be huddled together in some sort of sand plot. But, I am surprised that they have very good conditions here. They are more equal to us than I had imagined, I wonder how else we are equal. But then, I also know that this is a whole different world, and I don't understand it. It makes me wonder what I don't understand about Finland, how traumatized Finns are after our own wars. It affects everyone. But how can I approach these children if they are very traumatized? I can't just go teach there in the same way I would with Finnish children.
}

In (re)considering how the Finnish-students had positioned the Cambodian participants in this project, the student-teachers also experienced discomfort and uneasiness regarding their own roles and positionality as pedagogues. 
Do I have to take into consideration that this child is an orphan? Should I approach this in a certain way? Does someone expect me to approach this in a certain way? I feel very confused about the balance between teaching and charity here. I'm not necessarily interested in being a do-gooder, but do I have to be that person, now that I'm here? I probably do. Maybe I am in the wrong place. It would be easier to just teach somewhere else.

The field that the Finnish student-teachers found themselves in, being not only culturally, economically, linguistically, musically, and pedagogically different from that which they were familiar with, but also vastly different to their expectations, disrupted not only their individual habitus, but also the doxa of the music education tradition into which they had all been initiated and grown accustomed. Drawing upon Bourdieu's (1977) writings on habitus as "the strategy-generating principle enabling agents to cope with unforeseen and ever-changing situations" (72), intercultural education scholar Andreas Pöllmann (2016) describes such disruptive experiences amidst "cross cultural mobility" as "habitus dislocation". However, unlike Pöllmann's descriptions of such dislocation, the Finnish student-teachers' "habitus dislocation" was not necessarily experienced as a positive stimulant for "the development of students' intercultural reflexivity and practical intercultural sense" (Pöllmann 2016, 9). Indeed, at times student-teachers described experiencing this dislocation as an act of violence that "brutally disrupted" the "routine adjustment of subjective and objective structures" that constituted their habitus (Bourdieu and Wacquant 1992, 45). Whereas Gesche and Makeham note that intercultural competence is developed as part of a stress-adaptation-growth process that requires the "manoeuvring in and out of challenging situations that push individuals into a developmental upward spiral of increased adaptive capacity" $(2010,245)$, the intensity and inability for student-teachers to manoeuvre out of this uncertainty may have contributed towards experiences of crisis, frustration, and the desire to disengage and take refuge in security.

It would be nice if I could forget about these children's backgrounds. I just want to get on with it and teach.

\subsection{Disrupting the Musico-pedagogical Script}

Such refuge was often found in familiar scripts of teaching and learning music. Whereas uncertainty arose when the accepted common scripts did not transfer to the intercultural immersion contexts, the discomfort that resulted from such situations also allowed for a growing awareness of the pedagogical doxa underlying their own teaching and learning. For example, student-teachers recognized that much of their education remained unquestioned, as "in Finland, we are all a part of the same education system. We accept it." However, in the Cambodian contexts, what studentteachers regarded as commonsensical was at times interpreted in entirely different ways. 
Something is happening all the time here, there are never any breaks. I mean, they don't even understand the concept of a break. Yesterday, I told the children that they could have a five-minute break, and they all left and never came back.

In losing a feel for "what is to be done in a given situation" (Bourdieu 1990, 146), student-teachers described a lack of "the practical mastery of the logic or of the imminent necessity of a game - a mastery acquired by experience of the game, and one which works outside conscious control and discourse" (Bourdieu 1990, 61). Furthermore, the "schemes of action" (Bourdieu 1998) that student-teachers had learned and followed in the Finnish university context seemed to be nontransferrable, and were no help in "facilitating the substitutability of one reaction for another (...) enabling the agent to master all problems of a similar form" in new situations (Bourdieu 1990, 94). As such, student-teachers' work was an intensely challenging improvisatory experience, requiring them to "juggle multiple goals as well as handle complexity in [unfamiliar] here-and-now pedagogical situations" (Westerlund et al. 2015, 70).

Here in Cambodia we always have to improvise. There is no ready-made pattern for us to follow. We never know what is expected from us, or what they would like us to do. Our planAs never work, and our plan-Bs are often impossible - it is like having the rug pulled out from under our feet again, and again, and again.

These complex and unpredictable situations meant that student-teachers experienced new structural forces at work, and consequently a loss of "power to impose the legitimate vision of the social world (...), its present meaning and the direction in which it is going and should go" (Bourdieu 2000, 185). The student-teachers often experienced such forces as a hindrance to progress and development, with some comparing teaching and learning in Finland and in the Cambodian NGOs through deficit narratives of the Cambodian staff and children. These structural forces were experienced not only in teaching but also when learning Cambodian music and dance with the local teachers.

There's no systematic approach to learning to play together. I don't even know if it's controlled chaos or genuine chaos, but it's not very well organized or systematic. If we can't get it right, we are told 'start over', 'start over', 'start over'. It feels very mechanical, like they only have one way to learn a piece. If someone makes a mistake you immediately hear 'NO!' and then it's back to the beginning again. At some point I wanted to scream: 'just let me perform'! In Finland you always have to be encouraging as a teacher, and say something good first before you give negative comments.

Student-teachers' misrecognitions (Bourdieu and Wacquant 1992) of difference for deficit may be seen as attempts to regain security and certainty by consulting the musico-pedagogical script of Finnish music education. Education scholar David James explains that misrecognition refers to "an everyday and dynamic social process where one thing (...) is not recognised for what it is because it was not previously 'cognised' within the range of dispositions and propensities of the habitus of the person(s) confronting it" $(2015,10)$. In this way, the Finnish student-teachers attempted to reinstate familiar rules of a familiar game, according to which Cambodian staff or children were labelled as unable to perform, teach, or learn 
'properly'. As such, although student-teachers may have recognized that the doxa of Finnish music education was unsustainable in this new context, they still clung to it in search of comfort and security through appealing to what they assumed were universal grounds.

The concept of a peaceful work environment is quite weak, and the space is so poorly designed for music with bad acoustics. I mean we can't really achieve good things very efficiently because of the noise. They [the Cambodian staff and children] can tolerate so much noise - whereas I am constantly requiring silence! It is important for them to realize that music starts from silence.

Susan Conkling (2015) draws upon Ellsworth's (2005) writings in relation to a similar project involving university music education student-teachers traveling from the United States to Bali, noting that those "who invent ways to see and say new things through [pedagogy] do not preexist it but are rather invented in the process.... Teachers [are] in the making themselves" (Conkling 2015, 28). Our analysis here suggests that these processes of "wonderful transformation" (Conkling 2015, 193) amongst pre-service music teachers do not necessarily flow in a single, unwavering direction towards the mastery of visions of intercultural competence. If, as Hilgers states, "[h]abitus is constituted and determined according to a probable future that it helps actualize through anticipation" $(2009,740)$, it is not surprising that losing a feel for the future - losing the clarity of visions - can result in crisis. Self-making is indeed difficult work.

\subsection{Reflexive Becomings and the Transformation of Habitus}

The aims of the intercultural project were not only to gain an awareness and appreciation of cultural, musical, and pedagogical worlds very different from those with which the Finnish student-teachers were familiar, but also to provide an "experience of themselves while meeting an unknown culture [contributing to an] awareness of their own viewpoints, choices and actions" (Danielsen 2012, 99). In the latter stages of the project, student-teachers noted that the reflection sessions provided essential intercultural learning tools.

Coming from a totally different environment and being used to doing things a different way, this has really shaken me up. I can't rely on my assumptions anymore. I have often heard during my studies that the purpose of our education is that we learn to reflect, but it's only now that I realize that reflection is a way of teaching and working all the time. As a teacher you have to be able to analyze what you are doing, and what is happening in your classroom. That's the only way to survive this.

The pedagogical reflection session held halfway through the project, where student-teachers engaged with an academic text reporting research conducted on a similar intercultural immersion (though in very different cultural and musical contexts), particularly afforded student-teachers some distance to the intensity of their own experiences. Student-teachers found comfort in each other's expressions of 
uncertainty and discomfort, and also shifted from delineating the boundaries between "us" and "them" to identifying commonalities.

I was thinking about how I had learnt to play the folk guitar, and it was actually very similar [to the teaching and learning in Cambodia]. The teacher played first, then I imitated her, and we played it again, and again, and again until it was ingrained in my DNA. So, it's not that different after all. Actually, I really enjoyed learning the guitar.

Student-teachers were also discovering new ways to teach in the Cambodian context.

At some point I just hit a wall - I had to take a fifteen minute break. While I was sitting on the side of the room wondering if I could keep going, I watched the kids. They corrected themselves and guided each other as a group. The noise was infernal, but it was at the same time wonderful. I realised that as soon as I stopped standing right next to them, and stopped giving them advice all the time, they did it much better on their own. I was just messing them up and getting in the way. The second I stopped teaching, one of them took the role, and they worked as a team. I need to trust my students more.

Through their experiences teaching and learning at the Cambodian NGOs, the student-teachers also came to question some of the most central visions of Finnish music education, such as student-centered pedagogies, and participatory democracy in the classroom. They reflected upon their own discomfort, holding the mirror up to their own assumptions and narrations of what the visions of Finnish or Cambodian music education really are, and the extent to which they are enacted in practice.

Are we [Finns] actually a lot more teacher-centered than they are? We are so concerned with holding the reins the whole time - to be in control as a teacher. Initially I thought that teaching here was very authoritarian. But maybe things are not so black and white.

\section{Discomforting Visions of Intercultural Competence}

Research has suggested that intercultural music education courses can have "dramatic effects on the attitudes and beliefs of preservice music teachers" (Emmanuel $2003,39)$ through the development of intermusicality and intercultural understandings (Hebert and Saether 2014, 432). Without a shared language, musical or pedagogical repertoire, or cultural history, the intercultural project described in this chapter put the Finnish student-teachers in the situation where they could not always rely upon their pre-existing visions of what music education should be. They were required to negotiate new and unfamiliar interests and agendas, both as individuals and as a group through co-teaching and learning together. Through these negotiations, they identified shared values and principles, and through teaching practice, they learned what did and did not work. As such, the scripted visions and values of good music teaching into which student-teachers themselves had been initiated were also challenged and served as a focus for joint reflection and emerging reflexivity towards what is considered good music teaching in Finland. It was through such enhanced reflexivity, and growing self-awareness, that student-teachers began 
to "identify and [gain] (...) (relative) control over their own disposition[s]" (Hilgers 2009, 738). In other words, student-teachers were able to identify and gain control over the doxa of Finnish music education - the taken-for-granted good of teaching and learning of music, and reconstruct their own habitus as sites of transformation. As discussed in this chapter, this was not comfortable work. Challenging doxa and one's own habitus is perhaps necessarily discomforting work - not in the sense that transformation and learning requires student-teachers to feel uncomfortable and threatened all the time, but in the sense that leaving their comfort zones is productive (in the generative sense). As Bourdieu (1999) states, some degree of discomfort may be necessary in opening "the possibility of an emancipation founded on awareness and knowledge of the conditionings undergone and on the imposition of new conditionings designed durably to counter their effects" (Bourdieu 1999, 340).

As seen through the composite narrative excerpts, student-teachers' achievements were not necessarily framed as the acquisition of skills or knowledge regarding the musics or pedagogies of cultural Others. And as Deardorff (2009) suggests, knowledge and skills do not equate with intercultural competence. According to her framework, intercultural competence is comprised of five interrelated elements: attitudes (respect, openness, curiosity, discovery), knowledge (cultural selfawareness, culture-specific knowledge, sociolinguistic awareness), skills (observation, listening, evaluating, analyzing, interpreting, relating), internal outcomes (flexibility, adaptability, an ethnorelative perspective and empathy), and external outcomes (behavior, communication). In light of the research reported in this chapter, this framework raises an important question: when can we deem a teacher to be interculturally competent? We would argue that in gaining control over one's dispositions in order to negotiate and navigate new spaces of intercultural teaching and learning, one can never acquire the 'correct' attitude, knowledge, skills or outcomes to transcend all fields of play (cf. Pöllman 2016). If such attainment were possible, one could simply replace the old doxa of music education with new, unreflected values and practices. In other words, whilst institutional reflexivity "has its roots in how expert knowledge promotes radical doubt, this reflexivity is itself the basis of re-envisioning order and security" (Heaphy 2007, 83, italics added). As the world shifts towards a globalized, unitary framework of experience (Giddens 1994, 97) in which there are no 'Others', all are expected to be able to transcend the taken-forgranted games. Such an intercultural world can be described through what Chantal Mouffe has called "agonistic pluralism" (Mouffe 2005, 105). We cannot avoid the hegemonic nature of social relations and identities, but only come to terms with it, and be receptive to the multiplicity of voices and to the complexity of their power structures, to leave room for heterogeneity (Mouffe 2013, 49).

Hence, "heightened reflexivity" (Giddens 1994, 17) is then only the starting point for intercultural competence, rather than the end goal. Intercultural visions of music education allow for students (and their teachers) to have "a small chance of knowing what game we play and of minimizing the ways in which we are manipulated by the forces of the field in which we evolve" (Bourdieu and Wacquant 1992, 198-199). Thus, "reflexive vigilance" may well be an essential component of intercultural competence, as the ability and willingness to constantly analyze how power 
operates, "no matter how painful it may be" (Bourdieu and Wacquant 1992, 88-89). This is an unsettled and unsettling, lifelong process of 'becoming' (Deardorff and Jones 2012), rather than one of acquiring knowledge or cultivating attitudes and skills.

Acknowledgements We would like to acknowledge that this project and research would have not have been possible without the generosity of the three Cambodian NGO sites who participated in this intercultural project. We would also like to thank the Ministry for Foreign Affairs of Finland for partially funding the project. This publication has been undertaken as part of the Global Visions through Mobilizing Networks project funded by the Academy of Finland (project no. 286162).

\section{References}

Agar, M. (1990). Text and fieldwork: Exploring the excluded middle. Journal of Contemporary Ethnography, 19(1), 73-88.

Bartleet, B.-L. (2011). Stories of reconciliation: Building cross-cultural collaborations between indigenous musicians and undergraduate music students in Tennant Creek. Australian Journal of Music Education, 2, 11-21.

Bauman, Z. (2010). 44 letters from the liquid modern world. Malden: Polity Press.

Bauman, Z., May, T. (2001). Thinking sociologically (2nd edn). (orig. 1990). Malden: Blackwell Publishers.

Belz, M. J. (2006). Opening the doors to diverse traditions of music making: Multicultural music education at the university level. Music Educators Journal, 92(5), 42-45.

Bourdieu, P. (1977). Outline of a theory of practice (R. Nice, Trans.). New York: Cambridge University Press.

Bourdieu, P. (1990). In other words: Essays towards a reflexive sociology. Stanford: Stanford University Press.

Bourdieu, P. (1998). The scholastic point of view. In Practical reason: On the theory of action (R. Johnson et al., Trans.). Stanford: Stanford University Press.

Bourdieu, P. (1999). Scattered remarks. European Journal of Social Theory, 2, 334-340. https:// doi.org/10.1177/13684319922224563.

Bourdieu, P. (2000). Pascalian meditations. Stanford: Stanford University Press.

Bourdieu, P., \& Passeron, J-C. (1990). Reproduction in education, society and culture (R. Nice, Trans.). London: Sage.

Bourdieu, P., \& Wacquant, L. J. D. (1992). An invitation to reflexive sociology. Chicago: University of Chicago Press.

Bradley, D. (2007). The sounds of silence: Talking race in music education. Action, Criticism and Theory for music education, 6(4), 132-162.

Bresler, L. (2005). What musicianship can teach educational research. Music Education Research, $7(2), 169-183$.

Campbell, P. S. (2004). Teaching music globally. Belmont: Wadsworth.

Conkling, S. W. (2015). Utopian thinking, compliance, and visions of wonderful transformation. In S. W. Conkling (Ed.), Envisioning music teacher education (pp. 181-194). Lanham/ Boulder/New York/London: Rowman \& Littlefield.

Danielsen, B. A. B. (2012). Praksisbegrepet i musikklærerutdanningen [The notion of practicum in music teacher education]. In B. A. B. Danielsen \& G. Johansen (Eds.), Educating music teachers in the new millennium. Multiculturalism, professionalism and music teacher education in the contemporary society. A report from a Research and Development project (pp. 89-108). Oslo: NMH. 
Deardorff, D. (Ed.). (2009). The SAGE handbook of intercultural competence. Thousand Oaks: Sage.

Deardorff, D. K., \& Jones, E. (2012). Intercultural competence: An emerging focus in postsecondary education. In D. K. Deardorff, H. de Wit, J. Heyl, \& T. Adam (Eds.), The Sage handbook of international higher education (pp. 283-303). Thousand Oaks: Sage.

Ellsworth, E. (2005). Places of learning: Media, architecture, pedagogy. New York: Routledge.

Emmanuel, D. T. (2003). An immersion field experience an undergraduate music education course in intercultural competence. Journal of Music Teacher Education, 13(1), 33-41.

Gates, T. (2009). Introduction: Grounding music education in changing times. In T. A. Regelski \& J. T. Gates (Eds.), Music education for changing times: Guiding visions for practice (pp. xiv-xxx). London: Springer. https://doi.org/10.1007/978-90-481-2700-9.

Gesche, A. H., \& Makeham, P. (2010). Creating conditions for intercultural and international learning and teaching. In M. Hellstén \& A. Reid (Eds.), Researching international pedagogies. Sustainable practice for teaching and learning in higher education (pp. 241-258). London: Springer.

Giddens, A. (1994). Beyond left and right: The future of radical politics. Cambridge, MA: Polity Press.

Hammerness, K. (2015). Visions of good teaching in teacher education. In S. W. Conkling (Ed.), Envisioning music teacher education (pp. 1-20). Lanham/Boulder/New York/London: Rowman \& Littlefield.

Heaphy, B. (2007). Late modernity and social change. Reconstructing social and personal life. London/New York: Routledge.

Hebert, D., \& Saether, E. (2014). 'Please, give me space': Findings and implications from an evaluation of the GLOMUS intercultural music camp, Ghana 2011. Music Education Research, $16(4), 418-435$.

Hilgers, M. (2009). Habitus, freedom, and reflexivity. Theory and Psychology, 19(6), 728-755.

Jackson, A. Y., \& Mazzei, L. A. (2012). Thinking with theory: Viewing data across multiple perspectives. London: Routledge.

James, D. (2015). How Bourdieu bites back: Recognising misrecognition in education and educational research. Cambridge Journal of Education, 45(1), 97-112. https://doi.org/10.1080/030 5764X.2014.987644.

Joseph, D., \& Southcott, J. (2009). Opening the doors to multiculturalism: Australian pre-service music teacher education students' understandings of cultural diversity. Music Education Research, 11(4), 457-472.

Kallio, A. A. (2015). Factional stories: Creating a methodological space for collaborative inquiry in music education research. Research Studies in Music Education, 37(1), 3-20.

Karlsen, S., Westerlund, H., \& Miettinen, L. (2016). Intercultural practice as research in music education: The imperative of an ethics-based rationale. In P. Burnard, E. Mackinlay, \& K. Powell (Eds.), The Routledge international handbook of intercultural arts research (pp. 369-379). New York: Routledge.

Kertz-Welzel, A. (2013). "Two souls, alas, reside within my breast": Reflections on German and American education regarding the internationalization of music education. Philosophy of Music Education Review, 21(1), 52-65.

Lather, P. (2016). The work of thought and the politics of research: (Post)qualitative research. In N. K. Denzin \& M. D. Giardina (Eds.), Qualitative inquiry and the politics of research (pp. 97-118). Oxon: Routledge.

Leavy, P. (2013). Fiction as research practice: Short-stories, novellas and novels. Walnut Creek: Left Coast Press.

Mouffe, C. (2005). The democratic pradox. New York/London: Verso.

Mouffe, C. (2013). Agonistics. Thinking the world politically. London/New York: Verso.

Pöllmann, A. (2016). Habitus, reflexivity, and the realization of intercultural capital: The (unfulfilled) potential of intercultural education. Cogent Social Sciences, 2(1), 1149915. https://doi. org/10.1080/23311886.2016.1149915. 
Saether, E. (2013). The art of stepping outside comfort zones: Intercultural collaborative learning in higher music education. In H. Westerlund \& H. Gaunt (Eds.), Collaborative learning in higher music education: Why, what and how? (pp. 37-48). London: Ashgate.

Schippers, H. (2010). Facing the music: Shaping music education from a global perspective. Oxford: Oxford University Press.

Schubert, J. D. (2008). Suffering. In M. Grenfell (Ed.), Pierre Bourdieu: Key concepts (pp. $183-$ 198). Stocksfield: Acumen.

St. Pierre, E. A. (1997). Methodology in the fold and the irruption of transgressive data. International Journal of Qualitative Studies in Education, 10(2), 175-189.

Talbot, B. C., \& Mantie, R. (2015). Vision and the legitimate order. Theorizing today to imagine tomorrow. In S. W. Conkling (Ed.), Envisioning music teacher education (pp. 155-180). Lanham/Boulder/New York/London: Rowman \& Littlefield.

Volk, T. (1998). Music, education, and multiculturalism. Oxford: Oxford University Press.

Westerlund, H. (2017). Visions for intercultural teacher identity in C21st super diverse societies. In P. Burnard, V. Ross, H. J. Minors, K. Powell, T. Dragovic, \& E. Mackinlay (Eds.), Building intercultural and interdisciplinary bridges: Where theory meets research and practice (pp. 12-19). Cambridge: BIBACC Publishing.

Westerlund, H., Partti, H., \& Karlsen, S. (2015). Teaching as improvisational experience: Student music teachers' reflections on learning during an intercultural project. Research Studies in Music Education, 37(1), 55-75.

Open Access This chapter is licensed under the terms of the Creative Commons Attribution 4.0 International License (http://creativecommons.org/licenses/by/4.0/), which permits use, sharing, adaptation, distribution and reproduction in any medium or format, as long as you give appropriate credit to the original author(s) and the source, provide a link to the Creative Commons licence and indicate if changes were made.

The images or other third party material in this chapter are included in the chapter's Creative Commons licence, unless indicated otherwise in a credit line to the material. If material is not included in the chapter's Creative Commons licence and your intended use is not permitted by statutory regulation or exceeds the permitted use, you will need to obtain permission directly from the copyright holder. 